This is the author's final, peer-reviewed manuscript as accepted for publication. The publisher-formatted version may be available through the publisher's web site or your institution's library.

\title{
Failures in sprouts-related risk communication
}

Maria Sol Erdozain, Kevin J. Allen, Katija A. Morley, Douglas A. Powell

\section{How to cite this manuscript}

If you make reference to this version of the manuscript, use the following information:

Sol Erdozain, M., Allen, K. J., Morley, K. A., \& Powell, D. A. (2013). Failures in sproutsrelated risk communication. Retrieved from http://krex.ksu.edu

\section{Published Version Information}

Citation: Sol Erdozain, M., Allen, K. J., Morley, K. A., \& Powell, D. A. (2013). Failures in sprouts-related risk communication. Food Control, 30(2), 649-656.

Copyright: () 2012 Elsevier Ltd.

Digital Object Identifier (DOI): doi:10.1016/j.foodcont.2012.08.022

Publisher's Link: http://www.sciencedirect.com/science/article/pii/S0956713512004707

This item was retrieved from the K-State Research Exchange (K-REx), the institutional repository of Kansas State University. K-REx is available at http://krex.ksu.edu 
Running head: Sprouts risk communication

\title{
Failures in Sprouts-Related Risk Communication
}

\author{
Maria Sol Erdozain ${ }^{1}$, Kevin J. Allen², Katija A. Morley¹, Douglas A. Powell ${ }^{1}$
}

1 Department of Diagnostic Medicine/Pathobiology, College of Veterinary Medicine, Kansas State University, Manhattan, Kansas, 66506

2 Food, Nutrition and Health Program, Faculty of Land and Food Systems, The University of British Columbia, 218-2205 East Mall, Vancouver, BC, Canada, V6T $1 Z 4$

Address correspondence to:

Douglas A. Powell

Department of Diagnostic Medicine/Pathobiology

College of Veterinary Medicine

Kansas State University

1800 Denison Avenue

Manhattan, KS 66506-5606

Email: dpowell@ksu.edu

Google voice: 1-785-289-8165 


\begin{abstract}
Nutritional and perceived health benefits have contributed to the increasing popularity of raw sprouted seed products. In the past two decades, sprouted seeds have been a recurring food safety concern, with at least 55 documented foodborne outbreaks affecting more than 15,000 people. A compilation of selected publications was used to yield an analysis of the evolving safety and risk communication related to raw sprouts, including microbiological safety, efforts to improve production practices, and effectiveness of communication prior to, during, and after sprout-related outbreaks. Scientific investigation and media coverage of sprout-related outbreaks has led to improved production guidelines and public health enforcement actions, yet continued outbreaks call into question the effectiveness of risk management strategies and producer compliance. Raw sprouts remain a high-risk product and avoidance or thorough cooking are the only ways that consumers can reduce risk; even thorough cooking messages fail to acknowledge the risk of cross-contamination. Risk communication messages have been inconsistent over time with Canadian and U.S. governments finally aligning their messages in the past five years, telling consumers to avoid sprouts. Yet consumer and industry awareness of risk remains low. To minimize health risks linked to the consumption of sprout products, local and national public health agencies, restaurants, retailers and producers need validated, consistent and repeated risk messaging through a variety of sources.
\end{abstract}




\subsection{Introduction}

Consumption of sprouted seeds has become increasingly popular and is consistent with increased consumption of fresh fruits and vegetables (Schrader, 2002). Chemical analysis has shown that sprouts contain proteins, carbohydrates, minerals, and vitamins, making sprouts a nutritious food and popular option for vegetarians (Feng 1999). Over the past two decades though, fresh sprouts have been recognized as a significant food safety concern, with at least 55 sprout-associated outbreaks occurring worldwide affecting a total of 15,233 people. A comprehensive table of sprout-related outbreaks can be found at http://bites.ksu.edu/sprouts-associated-outbreaks (Erdozain, et al. 2011).

Sprouts present a unique food safety challenge compared to other fresh produce, as the sprouting process provides optimal conditions for the growth and proliferation of pathogenic bacteria. The sprout industry, regulatory agencies, and the academic community have been collaborating to improve the microbiological safety of raw sprouts, including the implementation of Good Manufacturing Practices (GMP), establishing guidelines for safe sprout production, and chemical disinfection of seed prior to sprouting. However, guidelines and best practices are only as good as their implementation. The consumption of raw sprouts is considered high-risk, especially for young, elderly and immuno-compromised persons (FDA, 2009).

This analysis covers the history of sprout-related food safety risk communication and development of sprout risk management guidance. A longitudinal analysis of outbreakrelated risk communication and policy response was used to detail the effective and ineffective strategies for communication of risk to the consuming public and current risks associated with consuming fresh sprouts. Case studies are used to create a framework for more effective future communications with the numerous stakeholders.

\subsection{Methodology}

Individuals use different sources to collect information and remain informed about any number of pertinent issues. A selection of publications, journals, and media articles concerning raw sprouts were used to construct a timeline of evolving scientific knowledge and public discussion from 1997 to 2012. The articles used for this analysis were retrieved from a database maintained at bites.ksu.edu covering the past 15 years of sprout-related events, as well as additional Internet-based searches of available academic, regulatory and public documents related to sprout-safety. The database contains files collected daily from Google Alerts in the Google mail account for bites.ksu.edu using search words such as E. coli, E. coli O157:H7, E. coli O104, Salmonella, Outbreaks, Illness, Sprouts, FDA, CDC, and CFIA. Articles collected included press releases, regulatory advisements, guidance statements, scientific journal articles, and media articles from local and national newspapers and newswires. 
Once the articles were collected, a review and analysis were conducted on the public communications related to sprout safety and the current risk management guidelines for sprout production. Microbiological concerns and government-issued public advisories were explored to better understand shortcomings and strengths observed prior to, during, and after sprout-related outbreaks.

Exploratory case studies were used to identify communication activities that may have impacted public safety. This approach is well-established (Stake, 1995). Documents were used to establish the chronology of events in each case and develop detailed case descriptions. Embedded case study analyses, as described by Yin (2003), focused on the communication activities of the related social actors, including crisis communication efforts, and the responses to these activities by other governments and the public. This type of case study is commonly used where considerable uncertainty exists about the operations, goals, and results of an incident (Datta, 1990).

\subsection{Results}

\subsubsection{Microbiology}

Numerous pathogens have either been implicated in sprout-associated outbreaks or identified as potential food safety concerns due to their ability to proliferate during sprouting (NACMCF, 1999). These include Bacillus cereus, Listeria monocytogenes, Shiga toxin-producing Escherichia coli, Shigella spp., Salmonella enterica serovars, and Yersinia enterocolitica.

Studies have evaluated the microbiological quality, composition, and presence of foodborne pathogens in retail raw sprouts. In 1980, Paterson and Wood reported total aerobic and coliform levels of $10^{8}$ and $10^{6} \mathrm{CFU} / \mathrm{g}$, respectively. In contrast to many ready-to-eat food products, the presence of coliforms in sprouts does not indicate production under insalubrious conditions. Rather, coliforms of environmental origin, such as Enterobacter spp. and Klebsiella spp., are considered normal flora, thereby limiting their use as a quality indicator as traditionally applied to foods.

When evaluating the retail microbiological quality of sprout products, existing microbiological guidelines for fresh, ready-to-eat produce are not suitable. In general, produce with counts $<5 \times 10^{4} \mathrm{CFU} / \mathrm{g}$ are considered good quality, but spoiled if levels exceed $5 \times 10^{7} \mathrm{CFU} / \mathrm{g}$. Sprouts, which are heavily colonized by bacterial biofilms during the sprouting process (Fett, 2000), are well recognized for their ability to support microbiological loads exceeding $10^{8} \mathrm{CFU} / \mathrm{g}$. Despite this, sprouts retain acceptable sensory characteristics that appeal to consumers and, as such, cannot be effectively evaluated using standard produce acceptability guidelines. In 1999 the United States National Advisory Committee on Microbial Criteria for Foods (NACMCF) stated that 
the observed levels of microorganisms in sprouts were not necessarily a concern, rather focus should be placed on determining the presence of pathogenic organisms.

New research on sprout risk reduction during sprout production began appearing in scientific journals in 1995 (Ponka et al, 1995; Health Canada, 1996; Jaquette et al, 1996; Puohiniemi et al, 1997). A study conducted at the University of Georgia concluded that common methods of treating seeds used for sprouting might not kill Salmonella (Jaquette et al, 1996). The sprouting environment, which facilitated the growth of Salmonella, was said to be a serious public health concern requiring urgent attention based on the recent association of sprouts with foodborne illness. The researchers stressed the result was not a recommendation for people to avoid sprouts at salad bars but to serve as a wake-up call for those who produced and prepared the product.

In an assessment of outgrowth during sprouting, levels of E. coli O157:H7 were shown to increase three logs within the first $24 \mathrm{~h}$, ultimately achieving maximal levels between $10^{5}$ to $10^{6} \mathrm{CFU} / \mathrm{g}$ (Stewart et al., 2001a). In an unrelated study, $10^{6}$ to $10^{7} \mathrm{CFU} / \mathrm{g}$ of $\mathrm{E}$. coli O157:H7 were observed within $48 \mathrm{~h}$ and remained at similar levels up to six days, even in the presence of chemical sanitizing agents (Taormina \& Beuchat, 1999). Similarly, Salmonella enterica serovars have been shown capable of achieving high levels during the sprouting process and possess saprophytic growth capacity in spent irrigation water (Howard \& Hutcheson, 2003). Sprout-associated illnesses from E. coli O157: H7 and Salmonella have consistently been linked to outbreaks, and have been documented in several countries, occurring in Europe as early as 1988 (Feng 1999, Taormina et al., 1999).

In India, 24 sprout samples available from street vendors and deriving from three sprout types were shown to possess high microbiological loads and coliform counts of $10^{9}$ to $10^{11}$ and $10^{7}$ to $10^{11}$, respectively (Viswanathan and Kaur, 2001). In Norway, a survey of 300 sprouted products deriving from a single producer were evaluated for overall quality, with thermotolerant coliforms present in approximately $25 \%$ of samples (Robertson et al., 2002); E. cloacae, E. sakazakii, and K. pneumonia ssp. pneumonia were typically present, while generic E. coli was isolated from eight (12.9\%) mung bean samples. In the U.S., a retail survey was conducted examining the presence of various foodborne pathogens in 200 retail sprout samples collected over a 1-year period (Samadpour et al., 2006). Twelve samples (6\%) were positive for enterohemorrhagic (EHEC) E. coli, three (1.5\%) of which were identified as E. coli 0157 and 14 samples $(7 \%)$ were positive for Salmonella. In Spain, a small microbiological survey of retail sprout products revealed similar issues (Abadias et al., 2008). Although none of the 15 samples assessed were positive for Campylobacter spp., E. coli O157:H7, or Yersinia enterocolitica, two $(13.3 \%)$ and four $(26.7 \%)$ samples were positive for L. monocytogenes and Salmonella, respectively; $40 \%$ of the samples tested positive for generic E. coli. 
Microbiological surveys have demonstrated the innate risks associated with sprout production. High bacterial populations are both normal and observed with retail sprouts. The inability to prevent on-farm contamination of seeds by pathogenic bacteria and a lack of heating prior to consumption translates to a food product frequently associated with outbreaks of foodborne disease. There are other potential consumer risks that are poorly described, but may be of considerable consequence to both healthy and vulnerable populations. These include risks associated with non-bacterial pathogenic microorganisms, cross-contamination, and the transmission of antimicrobial resistant bacteria and/or genes. Correspondingly, there is no one method that ensures safety of sprout seeds (Associated Press, 2011d; EFSA, 2011a).

Warm, moist conditions used during sprout production permits the rapid outgrowth of microorganisms associated with sprout seeds, the production environment, and water used for irrigation (Howard \& Hutcheson, 2003). Although pathogenic bacteria may originate from workers and production environments, prior on-farm contamination of seeds with low-levels of pathogenic bacteria is considered the primary food safety concern (Breuer et al, 2001; Como-Sabetti et al., 1997; Mahon, 1997; Mohle-Boetani et al., 2001; Winthrop et al, 2003). A lack of microbiological control steps following seed sprouting means that low concentrations of pathogens in seeds or the production environment may proliferate to high levels by the end of the sprouting process. Even with adherence to guidelines produced by the United States Food and Drug Administration (FDA) in which seeds were decontaminated with a wash of 20,000 ppm hypochlorite, bacteria were not eliminated from the finished sprouts (Stewart et al., 2001b). These results confirmed the need for pathogen-based end-product testing for production batches even when recommended decontamination steps are followed (Stewart et al., 2001b). Other research concluded that although bacteria such as E. coli O157:H7 and Salmonella may be injured during the decontamination process, no current practices will prevent sub-lethally injured cells from recovering and subsequently proliferating during the sprouting process (Lang et al, 2000).

The physical nature of sprouting seeds adds to the ability of bacteria to survive the decontamination process (Charkowski et al., 2001). Certain types of sprout seeds have more complex structures than others, affording pathogenic microorganisms an opportunity to avoid detection (Picklesimer, 2011). The different textures in seeds may also limit the ability to eliminate pathogens; rougher textured sprout seeds (e.g., broccoli and radish) carry more bacteria than smooth seeds and make pathogen removal more challenging (Charkowski et al., 2001; Picklesimer, 2011). High microbial populations facilitated by the germination process can act to minimize the ability to ensure the sprouted product is devoid of pathogenic microorganisms (Picklesimer, 2011). Further, poor traceability may increase the probability of continued use of contaminated seed, even for homegrown sprouts, as they can be widely distributed on an international scale (EFSA, 2011a). 


\subsubsection{Outbreaks}

There have been at least 55 confirmed outbreaks related to raw sprouts, the first reported in the U.K. in 1988 (Erdozain, et al. 2011; O'Mahony et al., 1990). The importance of sprouts as a significant source of foodborne illness was first recognized in North America following an international sprout-associated Salmonella Stanley outbreak in 1995 involving 17 U.S. states and Finland that sickened at least 242 people (Puohiniemi et al., 1997, Taormina et al., 1999). The implicated sprouts were grown by various producers who purchased seeds from a common distributor in the Netherlands.

In 1997, the first documented association between alfalfa sprouts and E. coli O157:H7 was observed in an outbreak in Michigan and Virginia (Los Angeles Times, 1997; Como-Sabetti et al., 1997). In response to this outbreak, the U.S. Centers for Disease Control (CDC) recommended that persons at high risk for severe complications from $E$. coli O157: H7 and Salmonella infections could reduce their risk by not eating sprouts (Como-Sabetti et al., 1997). This was the first recommendation from an organization to any group to avoid sprout consumption.

In 2003, an E. coli O157 outbreak was linked to sprouted seeds in Minnesota. The Minnesota Department of Agriculture (MDA) recommended the implicated lot of seeds not be used for production, correctly placing the food safety responsibility at the producer level rather than the consumer (Smith, 2003). MDA observed problems at the sprouting plant following inspection, pointing out that stronger enforcement of FDA guidelines were needed (Ferguson et al., 2005). The investigation traced the implicated alfalfa sprouts back to a single seed distributor from Australia, but the cultures and samples from the sprouter facility were negative for E. coli O157 (Ferguson et al., 2005). A few months later, a similar cluster of E. coli O157 was identified in Colorado (Ferguson et al., 2005). An investigation found an identical outbreak pattern and most of the isolates to the Minnesota outbreak, suggesting the seeds came from the same Australian seed distributor (Ferguson et al., 2005). Throughout the investigation and even after requests by the MDA and Colorado Department of Public Health and Environment (CDPHE), the FDA was hesitant to share information due to laws preventing release of commercial information (Ferguson et al., 2005).

In 2004, an outbreak in Georgia revealed a similar pulsed-field gel electrophoresis (PFGE)-type to those associated with the cases in Minnesota and Colorado (Walker, 2004), again suggesting a common seed supplier (Walker, 2004). The recurrent emergence of the contaminated seeds in different states and at different times highlights the traceability issues and ability of pathogens to survive on sprout seeds.

In 2005, the Canadian Food Inspection Agency (CFIA) warned the public that Wah Mung Bean Sprouts from Toronto Sun Wah Trading Inc. may have been contaminated with Salmonella (CFIA, 2005). At the time of this public announcement, more than 200 
cases had been confirmed (CBC News, 2005). No positive food samples for Salmonella were ever detected, possibly reflecting prior removal from the distribution system. No specific information was provided to customers.

Weeks after the 2005 Canadian Salmonella outbreak, sprouts were, once again, widely available with no new or additional risk management practices or risk messages from public health officials.

In 2010 the U.K. reported 125 cases of Salmonella linked to raw bean sprouts beginning in August (Food Standards Agency, 2010). The Food Standards Agency (FSA) recommended that if consumers were unclear on whether sprouts were ready-to-eat, "bean sprouts should be washed and thoroughly cooked as a precaution" (Agence France-Presse, 2010). There was no description of what thoroughly cooked meant. In Oct. 2010, microbiologists at the Health Protection Agency's Centre for Infections confirmed the link between bean sprouts and 141 cases of Salmonella Bareilly, yet the HPA and FSA maintained the safety of bean sprouts if "washed and cooked until piping hot" (Health Protection Agency, 2010). Professor Qutub Syed, a director with the HPA's Local and Regional Services Division commented that "no one should be put off eating bean sprouts, provided they are properly cooked" (Health Protection Agency, 2010), yet the best advice available regarding proper cooking remained to be "piping hot." Further, such messages do not consider cross-contamination risks associated with the handling of contaminated sprouts in commercial food production facilities or the home.

From November 2010 into 2011, an outbreak linked to raw sprouts in the U.S. and involving sandwich franchise Jimmy John's sickened 140 people (CDC, 2011; Illinois Department of Public Health, 2010). This was the third sprout related outbreak involving this franchise, yet the owner of the Montana Jimmy John's outlet, Dan Stevens, expressed confidence in his sprouts claiming that because the sprouts were locally grown they would not be contaminated (KRTV, 2010). By the end of December 2010 a sprout supplier, Tiny Greens Farm, was implicated in the outbreak (FDA, 2010). Jimmy John's owner, John Liautaud, responded by stating the sandwich chain would replace alfalfa sprouts with clover sprouts since they were allegedly easier to clean (Associated Press, 2011c). However, a week earlier a separate outbreak had been identified in Washington and Oregon in which eight people were infected with Salmonella after eating sandwiches containing clover sprouts from a Jimmy John's restaurant (Oregon Department of Human Services, 2011; Terry, 2011). This retailer was apparently not aware of the risks associated with sprouts, or even outbreaks associated with his franchisees.

The FDA inspection of the Tiny Greens facility found numerous failures which may have led to pathogen contamination. According to the FDA report, "the company grew sprouts in soil from the organic material decomposed outside without using any 
monitored kill step on it," mold was found in the mung-bean sprouting room, and the antimicrobial treatment for seeds was not demonstrated to be equivalent to the recommended FDA treatment (Roos, 2011). Months later, Bill Bagby Jr, owner of Tiny Greens, was quoted as saying "after the changes we made, it's next to impossible for anything to happen," hindering communication efforts by being defensive and overconfident (Des Garennes, 2011; Sandman \& Lanard, 2011). Bagby also expressed confidence in sprouts following the German E. coli O104 outbreak, commenting that for many like him, the nutritional benefits outweigh the risk: "Sprouts are kind of a magical thing. That's why I would advise people to only buy sprouts from someone who has a (food safety) program in place (that includes outside auditors). We did not have (independent auditors) for about one year, and that was the time the problems happened. The FDA determined that unsanitary conditions could have been a potential source of cross-contamination and so we have made a lot of changes since then." This message does not accurately communicate risk and may lead consumers to believe risk issues have been minimized.

In late December, 2011, less than one year after making the switch to clover sprouts, Jimmy John's was linked to another sprout related outbreak, this time it was E.coli O26 in clover sprouts (CDC, 2012a). In February 2012, sandwich franchise Jimmy John's announced they were permanently removing raw clover sprouts from their menus (Liddle, 2012). As of April 2012, the outbreak affected 29 people across 11 states (CDC, 2012a). Founder and chief executive, John Liautaud, attempted to appease upset customers through Facebook stating, "a lot of folks dig my sprouts, but I will only serve the best of the best. Sprouts were inconsistent and inconsistency does not equal the best." He also informed them the franchise was testing snow pea shoots in a Campaign, Illinois store, although there is no mention regarding the "consistency" or safety of this choice (Liddle, 2012). Jimmy John's was not the first of its kind to remove sprouts from the menu. Earlier in the year Erbert and Gerbert's Sandwich Shops removed alfalfa sprouts from their menu. Walmart stores stopped selling raw sprouts nationwide in 2010, along with other produce stores and markets (Denn, 2012). Walmart stated that they were undergoing research to assure safety of sprouts and reduce the risks associated with their consumption before re-introducing the product to their stores.

In 2011, the delayed reporting of cases between agencies due to a decentralized government and its agencies was a contributing factor in the Germany-based E. coli O104 outbreak that led to 53 deaths and over 4, 000 sick people (Dodd, 2011; Altmann et al, 2011). The E. coli strain responsible for the outbreak was unusually virulent, with high mortality and hemolytic uremic syndrome (HUS) rates observed in healthy adults (Kupferschmidt, 2011).

The uncertainties in any outbreak are enormous, and the pressures to get it right when providing risk information are tremendous. The outbreak began May 1-2, 2011. By May 26, Robert Koch Institute in Germany suspected the source to be linked to raw food and 
advised people not to consume "any tomatoes, cucumbers, or lettuce from northern Germany" (The Local, 2011). Cucumbers were further singled out as the source of the outbreak, when an EHEC strain was isolated from Spanish cucumbers; five days later health officials announced the strain was not the same as that of the outbreak strain (Huld, \& Kelland, 2011; Sandman \& Lanard, 2011), though it should have raised alarm that another potentially dangerous $E$. coli strain had been recovered from raw cucumbers.

Subsequently, Gert Lindemann, Lower Saxony's agriculture minister, announced raw bean sprouts were the likely cause of the outbreak, while other officials contradicted his affirmations despite epidemiological evidence (Courier Mail, 2011; Gardner, 2011; Associated Press, 2011a). In June, Reinhard Burger, president of the Robert Koch Institute, stated that the investigation of the outbreak pattern did suggest bean sprouts were responsible for the outbreak (Associated Press, 2011b) and on June 10, the warning against cucumbers, tomatoes and lettuce was cancelled. The outbreak had been linked to an organic sprout farm that was subsequently shut down by German officials. According to the German farm minister the farm had done nothing wrong and had the "highest quality standards". The minister for the environment and consumer protection in North-Rhine-Westphalia, Johannes Remmel, urged all consumers to report any suspicious vegetable sprouts (Kaufmann, 2011). The media reports and statements issued by German officials at this point provided little useful information to consumers and focused more on the impact on farmers than on the victims which by this point had reached over 3200 ill, 35 dead and was still growing.

Upon reporting of a similar outbreak in France, EFSA conducted a traceback investigation of both outbreaks concluding, two months after the outbreak began, that a specific lot of fenugreek seeds imported from Egypt were the likeliest source of contamination (EFSA, 2011b).

Issues with traceability and an inability to detect the causative agent in sprouts prevented effective public communication of risk. Correspondingly, the outbreak endured, resulting in one of the most aggressive and extensive foodborne illness outbreaks in history (Acheson, 2011).

\subsubsection{Guidelines and Recommendations}

In May 1999, NACMCF produced a report on microbiological safety evaluations and recommendations for sprouted seeds in which the authors concluded that contaminated seed was the likely source for most reported sprout-associated outbreaks (NACMCF, 1999). NACMCF proposed a range of measures to minimize the growth of pathogens during all sprout production stages, agreeing with the FDA that the potential for seed contamination would likely be reduced by implementation of Good Agricultural 
Practices (GAPs), but also stated that precluding contamination was unlikely (NACMCF, 1999).

In response to NACMCF recommendations, the FDA developed two guidelines for the sprout industry in October 1999 (FDA, 1999b; Bailey, 2000). This guidance identified a number of areas, from the farm to the sprouting facility, where the FDA believed immediate steps should be taken to reduce the risk of sprout-associated foodborne illness (FDA, 1999b) including: recommendations that seeds should be subjected to one or more approved treatments for reducing pathogens on seeds and sprouts; and, should be supplemented with microbiological testing of the spent irrigation water from each production lot to minimize the potential for distribution of a contaminated batch. Test results could be obtained as early as 48 hours after the beginning of the growing period, which ranges from 3 to 10 days, so producers could obtain results prior to shipping. Other recommendations included development and implementation of GAPs and GMPs in the production and packaging of seeds and sprouts. The second document outlined detailed procedures to be followed in implementing the testing procedures (Bailey, 2000).

Concurrently, the U.S. provided sprout growers, produce workers and the general public with relevant information and education resources. The National Center for Food Safety and Technology hosted a workshop on GMP's and Hazard Analysis and Critical Control Points (HACCP) intended for people involved in all aspects of the sprout industry, from seed growers to retail customers (National Center for Food Safety and Technology, 2000). The United States Department of Agriculture (USDA)/FDA foodborne illness education information center also announced the availability of food safety materials for the produce industry.

In September 2001, the Canadian Food Inspection Agency (CFIA) produced a Draft Code of Practice for the Hygienic Production of Sprouted Seeds that outlined two recommended areas for pathogen control. The first recommendation focused on GAPs to be used during seed production and the second on decontamination of seeds prior to sprouting. The CFIA stated that the use of this Code of Practice was not a guarantee of safe sprouts, and that there was currently no treatment available to ensure pathogenfree seeds (CFIA, 2007). The Code of Practice was amended in 2007 with continuing warning about the lack of treatment to ensure pathogen-free seeds (CFIA, 2007).

The Codex Alimentarius Commission (CAC) (2003) released similar guidelines in its Code of Hygienic Practice for Fresh Fruits and Vegetables, which included an annex for sprout production. The CAC is a collaboration between the Food and Agriculture Organization of the United Nations (FAO) and the World Health Organization (WHO), and was established in 1963 as an international point of reference for food safety. The developed Code was intended to ensure the safety of fresh fruits and vegetables, focusing on GAPs and Good Handling Practices (GHPs) to reduce the risk of microbial 
contamination. The annex for sprout production recognizes an increase in foodborne illness associated with raw sprouts, which most likely originate from the seed (CAC, 2003). As such, the recommendations focus on applying GAPs and GHPs during seed production and microbiological decontamination during sprout production. Even so, they acknowledge there are no treatments that can guarantee safety of seeds.

In 2006, Health Canada published guidance intended to reduce contamination of sprout seeds and beans through improved hygienic practices and sprout production practices. The document, "Policy to Manage Health Risk Associated with the Consumption of Sprouted Seeds and Beans," outlined a three-pronged approach to minimizing sprouts contamination. The Code of Practice for the Hygienic Production of Sprouted Seeds, "Guidance for Industry: Sample Collection and Testing for Sprouts and Spent Irrigation Water," addressed food safety issues relating to the quality of water and included educational material for consumers and industry to aid the public in understanding food safety issues, as well as outline industry's responsibility in the production of safe food (Health Canada, 2006).

The European Food Safety Authority (EFSA) (2011a) recommended that agricultural and handling practices during sprout production, harvest, and storage should be as stringent as those for fresh produce. These practices should include:

i. $\quad$ identifying seed crops intended for sprout production before planting;

ii. safe use of fertilizers and irrigation water;

iii. minimizing contamination of seeds with soil during harvest and preventing mechanical damage of seeds;

iv. ensuring that workers harvesting and handling seeds follow hygiene and health requirements;

v. ensuring that seeds are transported, processed and stored under conditions which will minimize the potential for microbial contamination;

vi. removing damaged seeds, from which it may be more difficult to remove pathogenic bacteria, or avoiding lots with too many damaged seeds;

vii. improving traceability of seed lots and minimizing, as far as possible, mixing of seed lots" (EFSA, 2011a).

Yet, as demonstrated by some of the case studies, guidance does not equate with verification.

\subsection{Discussion}

Due to their association with foodborne illness outbreaks involving E. coli O157: H7 and Salmonella spp., raw sprouts have emerged as a significant source of foodborne illness. Just as the E. coli O157: H7 Jack-in-the-Box outbreak in 1993 caused a surge in the public awareness of microbiological risks in food (Powell, 1997), the 1995 Salmonella outbreak 
in sprouts heralded the start of media interest in sprouts as a food safety risk in North America. The Jack-in-the-Box outbreak led to a sustained policy response and public discussion that resulted in the implementation of improved risk management practices such as mandatory HACCP in slaughterhouses (Powell et al., 2001). Similarly, the 1995 Salmonella outbreak in sprouts has resulted in a sustained policy response to develop appropriate risk management practices for the sprout industry.

With sprouts, risk reduction strategies such as treatments of seeds with sanitizing chemicals (20,000 ppm calcium hypochlorite) and following guidelines can be helpful, but not all producers comply. Furthermore, treatment of seeds is not always successful at eliminating pathogens, with varying factors such as soaking time, concentration and temperature having different outcomes (Montville \& Schaffner, 2004). Increased testing can minimize the distribution of pathogen-contaminated seed to producers and product to the consuming public; it cannot, however, ensure each lot is devoid of pathogens, even when no pathogens are detected using statistically valid sampling plans.

Repeated outbreaks involving raw sprouts call in to question the effectiveness of practices for decontamination of sprouted seeds and/or whether recommendations are actually being followed by sprout growers and producers. The effectiveness of guidelines and risk management strategies is unclear and in spite of continued measures by government, industry and scientists to reduce risk, the 55 documented sprout-related outbreaks and microbiological data indicate that sprouts remain a highrisk product for all consumers and avoidance is seen as the best way to reduce the risk of disease.

The risk associated with sprouts does not seem to be well understood by either consumers or the food industry, perhaps due to inconsistent and ineffective risk messages enhanced by the perception by individuals that they are impervious to risk. Sprouts continue to be promoted on menus and are marketed as nutritious and "extremely easy to grow," disregarding well-established food safety risks involved in their production (Gilbert, 2006). During the 2010-2011 outbreak linked to Jimmy John's, neither the representatives from Jimmy John's nor Tiny Greens Farms seemed to be aware of the risks associated with sprouts, even after 17 years of outbreaks.

Timely public communication, acknowledgement of both real and perceived risks, and control of related stigma are important factors in effective communications, especially during a crisis such as an outbreak of foodborne illness (Jacob, et al, 2011). Effective risk messages must provide concrete information that consumers (or producers) can relate to and act upon. Messages also need to be consistent, repeated, and articulated by different providers through multiple channels (Burns \& Slovic, 2012).

One of the first consumer warnings regarding sprouts was issued by CDC in 1997. During the late 1990s, Canada and the U.S. had several outbreaks of Salmonella- 
contaminated sprouts, however, only the U.S. continuously issued press releases warning high-risk groups of the risks associated with consumption of raw sprouts (Oregon Health Division, 1996). These warnings were eventually correctly expanded to everyone rather than just high-risk groups, and were republished frequently (FDA, 1999a; California Department of Health, 2000). In contrast, Canada did not issue a statement regarding the risks of consuming raw sprouts until 2002; instead, press releases warning about raw sprouts were limited to avoiding whichever brand was being recalled (Health Canada, 2002; CFIA, 1997). During this period, a Health Canada official stated that sprouts posed minimal risk for some people in the population; that high-risk groups should avoid eating sprouts but everyone else was probably safe although anyone that was worried about their sprouts should cook them (Laidlaw, 1999). It was not until late 2005 that communications from Canadian regulators became more consistent with U.S. warnings, and targeted the general population; this occurred only after 648 people were sickened with Salmonella in Ontario after eating raw bean sprouts (Health Canada, 2011).

Timely communication during a crisis is considered necessary to establish credibility in an information source, such as a government, industry, or business (Food and Agriculture Organization, 1999; Covello et al., 2001). Hance et al. (1988) state that people are entitled to information that affects their lives and that the early release of information sets the pace for resolution of the problem. Prompt communication also helps to shape public attitudes towards the risk. FAO and WHO have concluded that public attitudes, once formed, are difficult to change because people tend to listen to information that supports the belief they have formed (Food and Agriculture Organization, 1999).

One barrier to timely release of information during sprout outbreaks is that, like most fresh produce, sprouts are difficult to track and trace. This was highlighted by the various sprout-related outbreaks that popped up throughout the U.S. during 2003. In the 2005 Canadian sprout outbreak, the CFIA was never able to confirm the source of contamination making it difficult to give the public information on specific implicated lots to avoid. In such cases, it is essential to communicate the level of uncertainty and ensure completeness and consistency in the messaging. This includes the nature of the risk, the nature of the benefits that might be affected if the risk were reduced, the available alternatives, uncertainty in knowledge about risks and benefits, and management issues (U.S. National Research Council, 1989).

Public officials and industry representatives through the various outbreaks have generally failed to acknowledge the risk associated with fresh sprouts. Inconsistent, inaccurate and vague messages to wash sprouts or cook them to "piping hot" do not provide the risk information and specific alternatives that consumers need to make appropriate risk management decisions. After the 2005 Canadian sprout outbreak, the head of the Hastings and Prince Edward Counties Health Unit in Ontario exemplified 
this type of meaningless messaging by saying, "washing will probably get rid of most of it, millions and millions of people eat bean sprouts every day" (Ellsworth, 2006).

Acknowledgement of risks is also essential to building trust and credibility in communicators (Covello et al., 2001). Effective communicators listen to all parties involved, including the public, and accept them as partners (Covello, 2003; Food and Agriculture Organization, 1999). Jardine (2003) states that successful communication results from investing time and effort to understand what people know and believe. Further, Frewer et al. (1996) found that trust is gained or lost depending on whether provided information is proven right or wrong. Both denying real risks and ignoring non-risks perceived by the public as real risks could be detrimental to the communication process, and is a recurring issue in sprout-related risk communications.

\subsection{Conclusions}

Despite the frequent need for sprout-based risk communication, messaging with industry and public stakeholders has been limited in effectiveness. In spite of widespread media coverage of sprout-related outbreaks, improved production guidelines, and public health enforcement actions, awareness of risk remains low. Producers, food service and government agencies need to provide consistent, evidencebased messages and, more importantly, actions. Information regarding sprout-related risks and food safety concerns should be available and accurately presented to producers, retailers and consumers in a manner that relies on scientific data and clear communications.

In 2012 FDA and the Illinois Institute of Technology's Institute for Food Safety and Health (IIT IFSH) formed the Sprouts Safety Alliance (SSA) in an attempt to address some of these issues (FDA, 2012). The purpose of SSA is to develop programs that will educate and train people in the sprout production community, provide tools, and serve as a resource for sprout producers and federal and state agencies. SSA hopes to help sprout producers implement practices for the safe production of sprouts. 


\subsection{References}

Abadias, M., Usall, J. Anguera, M., Solsona, C. \& Vinas, I. (2008). Microbiological quality of fresh, minimally-processed fruit and vegetables, and sprouts from retail establishments. International Journal of Food Microbiology, 123, 121-9. doi: 101016/j.ijfoodmicro.2007.12.013

Acheson, D. (2011,Aug/Sept). Germany's E. coli nightmare. What can we learn from the deadly O104:H4 outbreak? Food Quality Magazine. Accessed April 25, 2012 from http://www.foodquality.com/view/0/index.html

Agence France-Presse. (2010, September, 29). Salmonella warning over raw bean sprouts. Retrieved April 12, 2012, from http://www.google.com/hostednews/afp/article/ALeqM5jXnYqoqKdax1St33BnAtXx _cMYFA?docId=CNG.7fe4eb3e1b0c4e67e43cdbf0d5c53172.821.

Altmann M., Wadl M., Altmann D., Benzler J., Eckmanns T., Krause G., Spode, A., \& an der Heiden, M. (2011, October). Timeliness of surveillance during outbreak of Shiga toxin-producing Escherichia coli, Germany, 2011. Emerging Infectious Diseases, 17. doi: 10.3201/eid1710.111027

Associated Press. (2011a, June 6). German officials: Sprouts not cause of E. coli outbreak. USA Today. Accessed July 22, 2011 from http://yourlife.usatoday.com/fitnessfood/safety/story/2011/06/German-officials-Sprouts-not-cause-of-Ecolioutbreak/48098098/1?csp=34news\&utm_source=feedburner\&utm_medium=feed\&utm _campaign $=$ Feed $\% 3 \mathrm{~A}+$ usatoday-NewsTopStories $\%$ 28News + +Top+Stories\%29\&utm_content=Google+Reader.

Associated Press. (2011b, June 10). Germany: Sprouts cause of E. coli outbreak. USA Today. Accessed July 22, 2011 from http:/ /yourlife.usatoday.com/health/medical/story/2011/06/Germany-Sproutscause-of-E-colioutbreak $/ 48272770 / 1$ ? csp=34news\&utm_source=feedburner\&utm_medium $=$ feed\&utm _campaign=Feed \%3A+usatoday-NewsTopStories+\%28News+-+Top+Stories\%29.

Associated Press. (2011c). Jimmy John's changing to clover sprouts. Chicago Sun-Times. Accessed July 22, 2011 from http:// southtownstar.suntimes.com/business/3255479420/sprouts-alfalfa-john-clover-jimmy.html.

Associated Press. (2011d, June 10). Like Sprouts? Experts say cook first to be safe. USA Today. Accessed July 22, 2011 from http://yourlife.usatoday.com/fitnessfood/ safety/story /2011/06/Like-sprouts-Experts-say-cook-first-to-be-safe--/48284608/1?csp=34news\&utm_source=feedburner\&utm_medium=feed\&utm_campai 
gn=Feed $\% 3 \mathrm{~A}+$ UsatodaycomHealth-TopStories+\%28News+-+Health++Top+Stories $\% 29$.

Bailey, C. (2000). Microbial testing of spent irrigation water during sprout production. U.S. Food and Drug Administration (FDA), reprinted from Food Safety Magazine JuneJuly 2000 issue. Accessed April 20, 2012

http:/ / www.fda.gov/Food/FoodSafety/ProductSpecificInformation/FruitsVegetablesJuices/ucm179788.htm

Breuer, T., Benkel, D. H., Shapiro, R. L., Hall, W. N., Winnett, M. M., Linn, M. J., Neimann, J., Barrett, T. J., Dietrich, S., Downes, F. P., Toney, D. M., Pearson, J. L., Rolka, H., Slutsker, L. \& Griffin, P. M. (2001). A multistate outbreak of Escherichia coli O157:H7 infections linked to alfalfa sprouts grown from contaminated seeds. Emerging Infectious Disease, 7, 977-82. Accessed April 20, 2012: http://wwwnc.cdc.gov/eid/

Burns, W.J. \& Slovic, P. (2012). Risk perception and behaviors: Anticipating and Responding to Crises. Risk Analysis, 32, 579-582. doi:10.1111/j.1539-6924.2012.01791.x

Canadian Food Inspection Agency (CFIA). (1997, November 10). Health hazard alert Alfalfa sprouts and sprout mixes containing alfalfa sprouts may contain Salmonella Bacteria. Accessed April 20, 2012 http://www.sproutnet.com/Research/health_hazard_alert1.htm

Canadian Food Inspection Agency (CFIA). (2005, December 24). Health hazard alert Mung bean sprouts manufactured by Toronto Sun Wah Trading may contain Salmonella bacteria. Accessed April 20, 2012 http://www.marketwire.com/press-release/cfiahealth-hazard-alert-mung-bean-sprouts-manufactured-toronto-sun-wah-trading-may573595.htm.

Canadian Food Inspection Agency (CFIA). (2007). Code of Practice for the Hygienic Production of Sprouted Seeds. Accessed April 20, 2012 http://www.inspection.gc.ca/english/fssa/frefra/safsal/sprointe.shtml\#xx.

CBC News. (2005, December 1). Don't eat Ontario bean sprouts for now, recall underway: health officials. Accessed April 20, 2012 http://www.cbc.ca/news/health/story/2005/11/25/bean-sprouts051125.html.

Charkowski, A., Sarreal, C. \& Mandrell, R. (2001). Wrinkled alfalfa seeds harbor more aerobic bacteria and are more difficult to sanitize than smooth seeds. Journal of Food Protection, 64, 1292-1298. Accessed April 20, 2012: http:/ / www.foodprotection.org/publications/journal-of-food-protection/ 
Centers for Disease Control and Prevention (CDC). (2011). Investigation update: multistate outbreak of human Salmonella i 4,[5],12:i:- infections linked to alfalfa sprouts. Accessed April 20, 2012 http://www.cdc.gov/salmonella/i4512i-/021011/index.html.

Centers for Disease Control and Prevention (CDC). (2012a). Multistate outbreak of Shiga Toxin-producing Escherichia coli O26 infections linked to raw clover sprouts at Jimmy John's Restaurants. Accessed April 20, 2012 http://www.cdc.gov/ecoli/2012/O26-02-12/index.html.

Centers for Disease Control and Prevention (CDC). (2012b). Tips from former smokers. Accessed April 20, 2012 http://www.cdc.gov/tobacco/campaign/tips/

Codex Alimentarius Commission. (2003). Code of hygienic practice for fresh fruits and vegetables (CAC/RCP 53-2003).

Como-Sabetti, K., Reagan, S., Allaire, S., Parrott, K., Simonds, C.M., Hrabowy, S., Ritter, B., Hall, W., Altamirano, J., Martin, R., Downes, F., Jennings, G., Barrie, R., Dorman, M.F., Keon, N., Kucab, M., Al Shab, A., Robinson-Dunn, B., Dietrich, S., Moshur, L., Reese, L., Smith, J., Wilcox, K., Tilden, J., Wojtala, G., Park, J.D., Winnett, M., Petrilack, L., Vasquez, L., Jenkins, S., Barrett, E., Linn, M., Woolard, D., Hackler, R., Martin, H., McWilliams, D., Rouse, B., Willis, S., Rullan, J., Miller, G., Henderson, S, Jr., Pearson, J., Beers, J., Davis, R. \& Saunders, D. (1997, August 15). Outbreaks of Escherichia coli infection associated with eating alfalfa sprouts-Michigan and Virginia, June-July 1997. MMWR, 46, 741-744. Accessed April 20, 2012 http://www.cdc.gov/mmwr/preview/mmwrhtml/00048994.htm

Courier Mail. (2011, June 6). German-grown beansprouts 'likely' cause of E. coli outbreak, officials say. Accessed April 20, 2012 http://www.couriermail.com.au/news/breaking-news/german-grown-beansproutslikely-cause-of-ecoli-outbreak-officials-say/story-e6freonf-1226069827245.

Datta, L. (1990) Case study evaluations. U.S. General Accounting Office transfer paper, 10.1.9. Washington D.C.

Denn, R. (2012, February 13). Looking for sprouts? You might have to look hard, and think twice. The Seattle Times. Accessed April 20, 2012 http://seattletimes.nwsource.com/html/allyoucaneat/2017496518_looking_for_sprout s_you_might.html.

Des Garennes, C. (2011, June 21). Sprouts farm owner cites steps he's taken. The NewsGazette. Accessed April 20, 2012 http:/ / www.newsgazette.com/news/agriculture/2011-06-21/sprouts-farm-owner-cites-steps-hestaken.html. 
Dodd, C. (2011). Multidisciplinary response to the E. coli O104 outbreak in Europe. Invited talk, Kansas State University.

Ellsworth, B. (2006). Bean sprout warning still in effect, but product safe. Belleville Intelligencer.

Erdozain, G. Erdozain, M. S. \& Powell, D. (2011). Sprouts associated outbreaks. bites. Accessed April 20, 2012: http:// bites.ksu.edu/sprouts-associated-outbreaks.

European Food Safety Authority (EFSA). (2011a). Scientific opinion on the risk posed by Shiga toxin-producing Escherichia coli (STEC) and other pathogenic bacteria in seeds and sprouted seeds. EFSA Journal, 9, 2424. doi:10.2903/j.efsa.2011.2424

European Food Safety Authority (EFSA). (2011b). Shiga toxin-producing E. coli (STEC) O104:H4 2011 outbreaks in Europe: Taking stock. EFSA Journal, 9(10), 2390. doi:10.2903/j.efsa.2011.2390

Feng P. (1999). A summary of background information and foodborne illness associated with the consumption of sprouts. U.S. Food and Drug Administration (FDA), Center for Food Safety and Applied Nutrition. Accessed April 20, 2012: http://www.sproutnet.com/Research/a_summary_of.htm

Ferguson, D.D., Scheftel, J., Cronquist, A., Smith, K., Woo-Ming, A., Anderson, E., Knutsen, J., DE, A.K. and Gershman, K. (2005). Temporally distinct Escherichia coli O157 outbreaks associated with alfalfa sprouts linked to a common seed source - Colorado and Minnesota, 2003. Epidemiology and Infection, 133, 439-447. doi: $10.1017 /$ S0950268804003589

Fett, W. F. (2000). Naturally occurring biofilms on alfalfa and other types of sprouts. Journal of Food Protection, 63, 625-32. Accessed April 20, 2012: http://www.foodprotection.org/publications/journal-of-food-protection

Food Standards Agency (FSA). (2010). Agency advice on cooking bean sprouts. Accessed April 20, 2012 http://www.food.gov.uk/news/newsarchive/2010/sep/sprouts2.

Gardner, C. (2011, June 5). German bean sprout farm identified as ground zero in E. coli outbreak. The Scotsman. Accessed April 20, 2012 http://news.scotsman.com/world/German-bean-sprout-farm-identified.6780197.jp.

Gilbert, T. (2006). Sprouts a powerhouse of vitamins. The Sudbury Star. 
Health Canada. (1996). Enterohemorrhagic E. coli infection Japan. Canada Communicable Disease Report, 22, 199-200.

Health Canada. (2002). Risks associated with sprouts. Accessed April 20, 2012 http://www.hc-sc.gc.ca/hl-vs/iyh-vsv/food-aliment/sprouts-germes-eng.php.

Health Canada. (2006). Policy on managing health risk associated with the consumption of sprouted seeds and beans. Accessed April 20, 2012 http:/ / www.hc-sc.gc.ca/fnan/legislation/pol/sprouts_pol_pousses-eng.php.

Health Canada. (2011). Risks associated with sprouts. Accessed March 19, 2012 from http://www.hc-sc.gc.ca/hl-vs/iyh-vsv/food-aliment/sprouts-germes-eng.php.

Health Protection Agency. (2010, October 7). Microbiology confirms a bean sprout link with Salmonella Bareilly cases. Accessed April 20, 2012 http://www.hpa.org.uk/NewsCentre/NationalPressReleases/2010PressReleases/1010 07BeansproutlinktosalmonellaBareilly/.

Howard, M. B., \& Hutcheson, S. W. (2003). Growth dynamics of Salmonella enterica strains on alfalfa sprouts and in waste seed irrigation water. Applied Environmental Microbiology, 69, 548-53. doi: 10.1128/AEM.69.1.548-553.2003

Huld, S., \& Kelland, K. (2011, May 26). Spanish cucumbers may be E. coli source, Germans say. Reuters. Accessed April 20, 2012

http://www.reuters.com/article/2011/05/26/us-germany-ecoliidUSTRE74P3ND20110526.

Illinois Department of Public Health. (2010). Salmonella outbreak investigation. Accessed April 20, 2012

http://www.idph.state.il.us/public/press10/12.17.10AlfalfaSproutss.htm.

Jaquette, C.B., Beuchat, L.R. \& Mahon, B.E. (1996). Efficacy of chlorine and heat treatment in killing $S$ stanley inoculated onto alfalfa seeds and growth and survival of the pathogen during sprouting and storage. Applied Environmental Microbiology, 62, 2212-2215. Accessed April 20, 2012: http://aem.asm.org/

Kaufmann, A. (2011, June 11). Germany confirms source of E.coli outbreak. Agence FrancePresse. www.google.com/hostednews/afp/article/ALeqM5g6NRcjMSGczScJJLVq903lBErTxA?docI $\underline{\mathrm{d}=\text { CNG.25b78f54a3b7e30abed76c9d803100d4.c1 }}$ 
KRTV. (2010, December 24). Jimmy John's in Montana: sprouts safe, grown in MT. Accessed April 20, 2012 http://www.krtv.com/news/jimmy-john-s-in-montanasprouts-safe-grown-in-mt/.

Kupferschmidt, K. (2011). EHEC-Infektion: "Was haben Sie gegessen?." Tagesspiegel. Accessed April 20, 2012 http:/ /www.tagesspiegel.de/wissen/was-haben-siegegessen/4213454.html.

Laidlaw S. (1999). Canadian sprout market dropping: panic reactions to US warnings about toxins in raw sprouts has hurt sales. The Toronto Star.

Lang, M. M., Ingham, B. H., Ingham, S. C. (2000). Efficacy of novel organic acid and hypochlorite treatments for eliminating Escherichia coli O157:H7 from alfalfa seeds prior to sprouting. International Journal of Food Microbiology, 58, 73-82. doi: 10.1016/S01681605(00)00297-X

Liddle, A. (2012, February 21). Jimmy John's pulls sprouts from menu. Restaurant News. Accessed April 20, 2012 http://nrn.com/article/jimmy-johns-pulls-sprouts-menu.

The Local. (2011, May 25). E. coli deaths continue as ministers warn of threat. Accessed April 20, 2012 http:// www.thelocal.de/national/20110525-35243.html.

Los Angeles Times. (1997, August 15). Tainted alfalfa sprouts sicken 70 people. Los Angeles Times. Accessed April 20, 2012

http://articles.latimes.com/1997/aug/15/news/mn-22693.

Mahon, B. E., Ponka, A., Hall, W. N., Komatsu, K., Dietrich, S. E., Siitonen, A., Cage, G., Hayes, P. S., Lambert-Fair, M. A., Bean, N. H., Griffin, P. M., \& Slutsker, L., (1997). An international outbreak of Salmonella infections caused by alfalfa sprouts grown from contaminated seeds. Journal of Infectious Disease, 175, 876-82. doi:10.1086/513985

Mohle-Boetani, J. C., Farrar, J. A., Werner, S. B., Minassian, D. Bryant, R. Abbott, S. Slutsker, L. \& Vugia D. J. (2001). Escherichia coli O157 and Salmonella infections associated with sprouts in California, 1996-1998. Annals of Internal Medicine, 135, 239-47. Accessed April 20, 2012: http:/ /www.annals.org/

Montville, R. I. and Schaffner, D.W. 2004. Analysis of published sprout seed disinfection studies shows treatments are highly variable. Journal of Food Protection. 67:758-765. Accessed August 25, 2012:

http://foodsci.rutgers.edu/schaffner/pdf\%20files/Montville\%20JFP\%202004b.pdf.

National Advisory Committee on Microbiological Criteria for Foods. (1999).

Microbiological safety evaluations and recommendations on sprouted seeds. Accessed 
April 20, 2012 http://www.fda.gov/food/foodsafety/productspecificinformation/fruitsvegetablesjuices/ucm078789.htm.

National Center for Food Safety and Technology. (2000). GMPS and HACCP for sprout growers a workshop sponsored by the National Center for Food Safety and Technology. Illinois Institute of Technology. Accessed April 20, 2012 http:/ / foodsafety.kstate.edu/en/news-details.php?a=1\&c=27\&sc $=221 \& i d=23971$.

O'Mahony, M., Cowden, J., Smyth, B., Lynch, D., Hall, M. \& Rowe, B. (1990). An outbreak of Salmonella Saint-Paul infection associated with bean sprouts. Epidemiology and Infection 104, 229-235. doi:10.1017/S0950268800059392

Oregon Health Division. (1996). Salmonellosis outbreak traced to alfalfa sprouts Oregon and B.C. Center for Disease Prevention \& Epidemiology 45. Accessed April 20, 2012

http://public.health.oregon.gov/DiseasesConditions/CommunicableDisease/CDSum maryNewsletter/Documents/1996/ohd4504.pdf

Oregon Department of Human Services. (2011). Salmonella outbreak prompts clover sprouts recall. Accessed April 20, 2012

http://www.oregon.gov/DHS/news/2011news/2011-0103.pdf.

Paterson, J.E., \& Wood, M.J. (1980). Klebsiella and other bacteria on alfalfa and bean sprouts at the retail level. Journal of Food Science, 45, 492-495. doi:10.1111/j.13652621.1980.tb04083.x

Picklesimer, P. (2011). Secret of safe sprout production is very clean seeds, expert says. University of Illinois College of Agricultural, Consumer and Environmental Sciences. Accessed April 20, 2012:

http://www.eurekalert.org/pub_releases/2011-10/uoic-sos101011.php

Ponka, A., Anderson, Y., Sitonen, A., deJong, B., Jahkola, M., Haikala, Kuhmonen, A., \& Pakkala, P. (1995). Salmonella in alfalfa sprouts. Lancet, 345, 462-463. doi:10.1016/S01406736(95)90451-4.

Powell, D., \& Leiss, W. (1997). The use of media analysis in risk communication research. In Mad Cows and Mother's Milk: The Perils of Poor Risk Communication. (Appendix) McGill -Queen's University Press. Montreal.

Powell, D., \& Leiss, W. (1997). Hamburger hell. In Mad Cows and Mother's Milk: The Perils of Poor Risk Communication. (p. 77-98) McGill -Queen's University Press. Montreal..

Powell, D., Blaine, K., Gomes, L., Grant, S.E., Lacroix, B., \& Morris, S. (2001). Best 
Communication Practices In Communicating A Drinkingwater-

Related Public Health Emergency. A Paper Prepared For The Walkerton Inquiry. Accessed April 10, 2012 from http://www.ontla.on.ca/library/repository/mon/1000/10294073.pdf

Puohiniemi, R., Heiskanen, T., \& Siitonen, A. (1997). Molecular epidemiology of two international sprout-borne Salmonella outbreaks. Journal of Clinical Microbiology, 35, 24872491

Robertson, L. J., Johannessen, G. S., Gjerde, B. K., \& Loncarevic, S. (2002). Microbiological analysis of seed sprouts in Norway. International Journal of Food Microbiology, 75, 119-26. doi:10.1016/S0168-1605(01)00738-3

Roos, R. (2011, February 7). FDA details hazards at Illinois sprout producer. Center for Infectious Disease Research \& Policy (CIDRAP) News. Accessed April 20, 2012 http://www.cidrap.umn.edu/cidrap/content/fs/fooddisease/news/feb0711sprouts.html.

Samadpour, M., Barbour, M. W., Nguyen, T., Cao, T. M., Buck, F., Depavia, G. A., Mazengia, E., Yang, P., Alfi, D., Lopes, M., \& Stopforth, J. D. (2006). Incidence of enterohemorrhagic Escherichia coli, Escherichia coli O157, Salmonella, and Listeria monocytogenes in retail fresh ground beef, sprouts, and mushrooms. Journal of Food Protection, 69, 441-3. Accessed April 20, 2012 http:/ / www.foodprotection.org/publications/journal-of-food-protection

Sandman, P. \& Lanard, J. (2011). Explaining and proclaiming uncertainty: Risk communication lessons from Germany's deadly E. coli outbreak. Accessed April 20, 2012 the Peter Sandman Risk Communication Website http:/ / psandman.com/col/GermanEcoli.htm.

Schrader, W.L. (2002). Sprout production in California. University of California Department of Agriculture and Natural Resources Publication 8060. Accessed April 20, 2012 from http://ucanr.org/freepubs/docs/8060.pdf

Smith, K. (2003). Letter to Kevin Elfering. Minnesota Department of Health.

Stake, R. (1995). The art of case study research, p. 123. Thousand Oaks, CA: Sage.

Stewart, D., Reineke, K., Ulaszek, J., Fu, T., \& Tortorello, M. (2001a). Growth of Escherichia coli O157:H7 during sprouting of alfalfa seeds. Letters in Applied Microbiology, 33, 95-9. doi:10.1046/j.1472-765x.2001.00957.x 
Stewart, D.S., Tortorello, M.L., Reineke, K.F., \& Ulaszek, J. M. (2001b). Growth of Salmonella during sprouting of alfalfa seeds associated with salmonellosis outbreaks. Journal of Food Protection, 64, 618-622. Accessed April 20, 2012:

http://www.foodprotection.org/publications/journal-of-food-protection.

Taormina, P. J., Beuchat, L. R., \& Slusker, R. (1999). Infections associated with eating seed sprouts: An international concern. Emerging Infectious Disease, 5, 629-634. doi:10.3201/eid0505.990503

Terry, L. (2011, January 3). Kent, Wash., company recalls sprouts after seven people sickened in Oregon, Washington. The Oregonian. Accessed April 20, 2012 http://www.oregonlive.com/business/index.ssf/2011/01/kent_wash_company_recall s_spro.html.

U. S. Food and Drug Administration (FDA). (1999a). Consumers advised of risks associated with raw sprouts. U.S. Department of Health and Human Services. Accessed April 20, 2012

http://www.scienceblog.com/community/older/archives/M/2/fda1190.htm

U.S. Food and Drug Administration (FDA). (1999b, October 27). Guidance for industry: Sampling and microbial testing of spent irrigation water during sprout production. Accessed April 20, 2012 http://www.fda.gov/Food/GuidanceComplianceRegulatoryInformation/GuidanceDo cuments/ProduceandPlanProducts/ucm120246.htm.

U.S. Food and Drug Administration (FDA). (2009, April 26). Raw alfalfa sprouts linked to Salmonella contamination. Accessed April 20, 2012

http://www.fda.gov/NewsEvents/Newsroom/PressAnnouncements/ucm149570.htm

U. S. Food and Drug Administration (FDA). (2010, December 27). FDA: Don't eat certain lots of tiny greens brand alfalfa sprouts or spicy sprout. Accessed April 20, 2012 http://www.fda.gov/NewsEvents/Newsroom/PressAnnouncements/ucm238188.htm

U. S. Food and Drug Administration (FDA). (2012, February 28). Sprouts Safety Alliance. Accessed August 25, 2012

http:/ /www.fda.gov/Food/FoodSafety/FSMA/ucm293429.htm.

U.S. National Research Council. (1989). Improving Risk Communication. Committee on Risk Perception and Communication. National Academy Press, Washington, D.C. pp. 332 
Viswanathan, P. \& Kaur, R. (2001). Prevalence and growth of pathogens on salad vegetables, fruits and sprouts. International Journal of Hygiene Environmental Health, 203, 205-13. doi:10.1078/S1438-4639(04)70030-9

Walker, B.J. (2004). E. coli O157:NM summary. Georgia Department of Human Resources. Accessed April 20, 2012 http:/ /www.sproutnet.com/Research/Georgia\%202004\%20Report\%20w\%20notes.pdf.

Winthrop, K. L., Palumbo, M. S., Farrar, J. A., Mohle-Boetani, J. C., Abbott, S., Beatty, M. E. Inami, G. \& Werner, S. B. (2003). Alfalfa sprouts and Salmonella Kottbus infection: a multistate outbreak following inadequate seed disinfection with heat and chlorine. Journal of Food Protection, 66, 13-7. Accessed April 20, 2012:

http://www.foodprotection.org/publications/journal-of-food-protection

Yin, R.K. (2003). Case study research: Design and method (3rd ed.), p. 50. Thousand Oaks, CA: Sage. 